\title{
Dampak Kondisi Makroekonomi terhadap Deposito Perbankan Syariah di Indonesia
}

\section{The Impact of Macroeconomic Variables towards Islamic Banking's Total Deposits in Indonesia}

\author{
Zaki Abdullah $^{1}$, Iman Sugema ${ }^{2}$, Asep Nurhalim ${ }^{3}$ \\ ${ }^{1}$ Departemen Ilmu Ekonomi Syariah, Institut Pertanian Bogor 16680, email: zakieksyar50@apps.ipb.ac.id \\ ${ }^{2}$ Departemen Ilmu Ekonomi, Institut Pertanian Bogor 16680, email: i.sugema@gmail.com \\ ${ }^{3}$ Departemen Ilmu Ekonomi Syariah, Institut Pertanian Bogor 16680, email: asepnu@ipb.ac.id
}

\begin{abstract}
Changes in macroeconomic conditions have an impact towards financial industry, particularly in the banking industry. This research aims to look at the impact of global financial crisis and macreconomic variables towards the total deposits of Islamic banking in Indonesia with the VECM method. The period of this study using monthly data from January 2006 until December 2016. The results showed that the global financial crisis has no effect towards the total deposits of Islamic banking in Indonesia. Then, based on the analysis of Impulse Response Function (IRF), the response of total deposits of Islamic banking in Indonesia towards inflation, equivalent rate and lending rate is positive. While the shocks level of conventional banking interest rate and industrial growth is negatively responded by total deposits in Islamic banking. The Forecast Error Variance Decomposition (FEVD) analysis results showed that equivalent rate and interest rate offered by each banking system give most contributed among other variables.
\end{abstract}

Keywords: macroeconomic, global financial crisis, islamic banking, mudharabah deposits, VECM

\begin{abstract}
Abstrak. Perubahan kondisi makroekonomi memberikan dampak terhadap industri keuangan, khususnya pada industri perbankan. Penelitian ini bertujuan untuk melihat pengaruh krisis keuangan global dan variabel makroekonomi terhadap total dana deposito pada perbankan syariah di Indonesia dengan metode VECM. Periode penelitian ini menggunakan data bulanan dari Januari 2006 sampai Desember 2016. Hasil analisis menunjukkan bahwa krisis keuangan global tidak berpengaruh terhadap total deposito pada perbankan syariah di Indonesia. Kemudian, berdasarkan hasil analisis Impulse Response Function (IRF) respon yang ditunjukkan oleh variabel total deposito terhadap guncangan tingkat bagi hasil, inflasi dan suku bunga pinjaman adalah positif. Sedangkan guncangan tingkat suku bunga bank konvensional dan pertumbuhan industri akan direspon negatif oleh total deposito perbankan syariah. Dari hasil analisis Forecast Error Variance Decomposition (FEVD), menunjukkan bahwa tingkat bagi hasil dan suku bunga deposito yang ditawarkan oleh masing-masing perbankan memberikan kontribusi paling besar di antara variabel yang lain.
\end{abstract}

Kata kunci: makroekonomi, krisis keuangan global, perbankan syariah, deposito mudharabah, VECM

\section{PENDAHULUAN}

Sejak disahkannya UU Nomor 7 tahun 1992 yang kemudian disempurnakan dengan UU Nomor 10 tahun 1998 perihal perbankan syariah, Pemerintah telah membuka peluang kepada para pelaku perbankan dan lembaga keuangan lainnya untuk mengoperasikan kegiatan usahanya dengan prinsipprinsip syariah yang menggunakan sistem bagi hasil dan bebas dari maysir, gharar, dan segala macam bentuk riba sebagaimana disampaikan dalam Al-Quran surat Ali Imran ayat 130 yang artinya "Hai orang-orang yang beriman, janganlah kamu memakan riba dengan berlipat ganda dan bertakwalah kamu kepada Allah supaya kamu mendapat keberuntungan".

Menurut Karim (2003) pada dasarnya produk perbankan syariah dapat dibagi menjadi tiga bagian besar, yaitu produk penyaluran dana, produk penghimpunan dan produk jasa. Terdapat dua jenis akad dalam penghimpunan dana oleh bank syariah, yaitu wadi'ah dan mudharabah. 
Pada produk dengan prinsip wadi'ah, bank syariah dapat memberikan imbalan kepada pemilik dana secara sukarela, namun tidak diperjanjikan sebelumnya. Pada produk dengan prinsip mudharabah, bank syariah memberikan imbalan kepada pemilik dana sebesar nisbah yang telah disepakati di awal akad. Namun secara keseluruhan produk penghimpunan dana perbankan syariah hampir sama dengan produk perbankan pada umumnya seperti giro, tabungan dan deposito. Perbedaan produk penghimpunan dana pada perbankan syariah dan konvensional adalah sistem pengembaliannya yakni bank konvensional menggunakan suku bunga sedangkan bank syariah menggunakan bagi hasil.

Dalam perkembangan perbankan syariah di Indonesia masih dipengaruhi oleh keberadaan sistem perbankan konvensional. Hal ini disebabkan oleh sistem perbankan di Indonesia yang masih mengacu pada BI rate. BI rate atau tingkat suku bunga Bank Indonesia merupakan suku bunga acuan dalam menentukan kebijakan dunia perbankan dan keuangan di Indonesia.

Dalam penelitian di beberapa negara, hasil menunjukkan adanya pengaruh keberadaan sistem perbankan konvensional terhadap perbankan syariah yang ada pada negara tersebut. Chong dan Liu (2008) dalam penelitiannya menemukan bahwa terdapat hubungan antara tingkat bagi hasil deposito pada perbankan syariah dengan suku bunga deposito bank konvensional. Haron dan Azmi (2008) dan Kasim et al. (2009) mengemukakan bahwa terdapat hubungan antara jumlah deposito yang disimpan pada perbankan syariah dengan suku bunga bank konvensional dan tingkat bagi hasil bank syariah. Selain itu, Beck et al. (2010) mengemukakan bahwa tingkat return pada deposito bank syariah mengikuti suku bunga deposito bank konvensional. Sehingga dapat disimpulkan ternyata meskipun sebuah negara memiliki bank dengan sistem yang berbeda, keduanya saling mempengaruhi, hal tersebut bisa menjadi hal yang positif maupun negatif.

Penelitian lain yang dilakukan oleh Abduh et al. (2011) mengenai dampak krisis dan variabel-variabel makroekonomi terhadap total deposito yang terdapat pada perbankan syariah di Malaysia. Hasil penelitian menunjukkan bahwa perbankan syariah memiliki ketahanan terhadap krisis keuangan global yang terjadi di Malaysia pada bulan keempat 2007 sampai bulan kedua belas 2008. Perbankan syariah memberikan kesan positif dan mendapatkan keperecayaan lebih dari para deposan selama krisis, dibuktikan dengan para deposan tidak menarik dana deposito mereka melainkan justru dana deposito semakin bertambah. Di Malaysia, perbankan syariah terbukti lebih tahan terhadap krisis keuangan.

Dalam penelitian ini, hal baru yang akan diungkap adalah ketahanan dunia perbankan terhadap krisis keuangan dan seberapa kuat pengaruh antara tingkat bagi hasil perbankan syariah dan suku bunga yang dimiliki bank konvensional terhadap ketertarikan nasabah dalam menyimpan dana deposito di bank. Sehingga hal tersebut dapat memberikan pelajaran bagi pelaku industri perbankan dalam menetapkan kebijakan untuk melakukan funding, khususnya pada penerapan di Indonesia yang memiliki mayoritas penduduk muslim namun menganut dual banking system.

\section{Rumusan Masalah}

Krisis keuangan global yang berawal dari kasus subprime mortgage di Amerika Serikat menimbulkan dampak yang luas bagi perekonomian dunia. Salah satu industri keuangan yang sedang tumbuh di Indonesia adalah sektor perbankan, di sisi lain perbankan menawarkan sistem alternatif berupa sistem yang menggunakan prinsip-prinsip syariah sejak tahun 1998.

Produk deposito adalah simpanan berjangka dan merupakan salah satu produk perbankan syariah yang menggunakan sistem bagi hasil berdasarkan laba dengan prinsip akad mudharabah. Produk deposito mudharabah adalah produk penghimpunan dana pihak ketiga yang terbesar dan berpengaruh dalam kegiatan dan kebijakan dunia perbankan syariah. 
Nisbah (tingkat bagi hasil) atau yang dikenal dengan equivalent rate merupakan faktor penting dalam menarik dana pihak ketiga dari nasabah. Di sisi lain, Indonesia adalah salah satu negara yang menerapkan dual banking system, dimana sistem perbankan syariah berjalan bersama-sama dengan sistem perbankan konvensional. Keberadaan sistem perbankan konvensional yang masih mendominasi di Indonesia ini memberikan pengaruh terhadap total dana pihak ketiga yang terdapat pada perbankan syariah di Indonesia, salah satunya adalah dengan adanya interest rate pada perbankan konvensional. Selain krisis dan karakteristik bank yang memengaruhi jumlah dana pihak ketiga pada bank, berdasarkan berbagai literatur faktor eksternal berupa kondisi makroekonomi juga berdampak pada jumlah dana pihak ketiga yang disimpan oleh masyarakat pada bank.

Berdasarkan uraian di atas, maka tujuan penelitian ini, antara lain menganalisis dampak krisis keuangan global terhadap total jumlah deposito mudharabah pada perbankan syariah di Indonesia, menganalisis dampak variabel-variabel makroekonomi terhadap total jumlah deposito mudharabah pada perbankan syariah di Indonesia, dan mengukur variabel yang paling dominan dalam mempengaruhi total jumlah deposito mudharabah pada perbankan syariah di Indonesia.

\section{METODE}

Jenis data yang digunakan pada penelitian ini adalah jenis data sekunder dengan bentuk data time series. Periode yang digunakan adalah periode bulanan dari Januari 2006 hingga Desember 2016. Sumber data penelitan berasal dari Otoritas Jasa Keuangan (OJK), International Financial Statistics, Badan Pusat Statistika (BPS), dan Bank Indonesia (BI). Variabel dan proksi data dapat dilihat pada Tabel 1.

Tabel 1 Variabel, proksi data, dan sumber

\begin{tabular}{lll}
\hline \multicolumn{1}{c}{ Variabel } & \multicolumn{1}{c}{ Proksi } & \multicolumn{1}{c}{ Sumber } \\
\hline $\begin{array}{l}\text { LTD (logaritma natural dari } \\
\text { total deposito) }\end{array}$ & $\begin{array}{l}\text { Total Deposito Perbankan } \\
\text { Syariah }\end{array}$ & $\begin{array}{l}\text { Statistik Perbankan Syariah OJK } \\
\text { dan Statistik Perbankan Indonesia } \\
\text { Bank Indonesia }\end{array}$ \\
$\begin{array}{l}\text { IR (Average of Islamic Banking } \\
\text { Equivalent Rate) }\end{array}$ & $\begin{array}{l}\text { Karakteristik Perbankan } \\
\text { Syariah }\end{array}$ & $\begin{array}{l}\text { Statistik Perbankan Syariah OJK } \\
\text { dan Statistik Perbankan Indonesia }\end{array}$ \\
CR (Average of Conventional & Karakteristik Perbankan & $\begin{array}{l}\text { Bank Indonesia } \\
\text { International Financial Statistics }\end{array}$ \\
Banking Interest Rate) & Konvensional & International Financial Statistics \\
CPI (consumer price index) & Inflasi & $\begin{array}{l}\text { Badan Pusat Statistika } \\
\text { IG (Industrial Growth) }\end{array}$ \\
LR (Lending Rate) & Pertumbuhan Ekonomi \\
CRISIS & Karakteristik Perbankan & $\begin{array}{l}\text { International Financial Statistics } \\
\text { Sugema (2012) }\end{array}$ \\
\hline
\end{tabular}

\section{Metode Pengolahan Data}

Penelitian ini menggunakan metode analisis VECM. Pengelompokkan data menggunakan Microsoft Excel 2013 dan diolah menggunakan Eviews 8. Penelitian ini menggunakan metode analisis VECM karena penelitian ini bertujuan untuk melihat perilaku jangka pendek Tabungan Deposito yang diwakili oleh variabel logaritma natural dari total deposito (LTD) pada Perbankan Syariah di Indonesia terhadap jangka panjangnya akibat adanya krisis keuangan global dan dampak variabelvariabel makroekonomi. 
Metode dan model dalam penelitian ini adalah sebagai berikut:

$\left[\begin{array}{c}\Delta L T D_{t} \\ \Delta I R_{t} \\ \Delta C R_{t} \\ \Delta C P I_{t} \\ \Delta I G_{t} \\ \Delta L R_{t}\end{array}\right]=\left[\begin{array}{c}\alpha_{10} \\ \vdots \\ \alpha_{60}\end{array}\right]+\left[\begin{array}{ccc}\alpha_{11} & \cdots & \alpha_{16} \\ \vdots & \ddots & \vdots \\ \alpha_{61} & \cdots & \alpha_{66}\end{array}\right]\left[\begin{array}{c}\Delta L T D_{t-1} \\ \Delta I R_{t-1} \\ \Delta C R_{t-1} \\ \Delta C P I_{t-1} \\ \Delta I G_{t-1} \\ \Delta L R_{t-1}\end{array}\right]+\left[\begin{array}{c}e_{1 t} \\ \vdots \\ e_{6 t}\end{array}\right]+C R I S I S$

Keterangan :

$\begin{aligned} \text { LTD } & \text { Logaritma Natural dari Total Deposito Perbankan Syariah (miliar rupiah) } \\ I R & =\text { Rata-rata tingkat bagi hasil deposito Perbankan Syariah }(\%) \\ C R & \text { Rata-rata suku bunga deposito Perbankan Konvensional }(\%) \\ \text { CPI } & \text { Consumer Price Index sebagai proksi terhadap inflasi (tahun dasar 2010=100) } \\ I G & \text { Pertumbuhan indeks produksi industri }(\%) \\ \text { LR } & \text { Suku bunga pinjaman }(\%) \\ \text { CRISIS } & \text { Variabel dummy krisis dimana terjadi pada bulan pertama tahun 2008 sampai } \\ & \text { bulan kedua belas tahun 2009 (M1-2008 sampai M12-2009). Dummy "1" untuk } \\ & \text { menunjukkan adanya krisis dan "0" untuk sebaliknya }\end{aligned}$

\section{HASIL DAN PEMBAHASAN}

Sebelum dilakukan pengolahan data menggunakan metode VECM, terlebih dulu dilakukan uji pra estimasi terhadap variabel-variabel di dalam model. Terdapat dua tipe uji akar unit dalam penelitian ini, yakni tipe uji Augmented Dickey-Fuller (ADF) dan Phillips-Perron (PP). Pada tipe uji ADF diketahui bahwa hanya terdapat dua variabel yang stasioner pada tingkat level, yakni Suku Bunga Deposito Perbankan Konvensional (CR) dan Pertumbuhan Industri (IG), sehingga dilakukan uji akar unit tipe ADF pada tingkat first difference. Hasil uji akar unit tipe ADF pada tingkat first difference menunjukkan semua variabel sudah stasioner pada taraf nyata 5 persen dan 10 persen. Pada tipe uji PP, diketahui bahwa hanya terdapat satu variabel yang stasioner pada tingkat level, yakni Pertumbuhan Industri (IG), sehingga dilakukan uji akar unit tipe PP pada tingkat first difference. Hasil uji akar unit tipe PP pada tingkat first difference menunjukkan semua variabel sudah stasioner pada taraf nyata 5 persen dan 10 persen. Pada Tabel 2 hingga Tabel 5 terlampir hasil uji akar unit dengan menggunakan tipe ADF dan PP.

Tabel 2 Hasil pengujian akar unit tipe ADF pada level

\begin{tabular}{|c|c|c|c|c|c|c|}
\hline \multirow{2}{*}{ Variabel } & \multirow{2}{*}{$\begin{array}{c}\text { ADF } \\
\text { Statistik }\end{array}$} & \multirow{2}{*}{$\begin{array}{c}\text { ADF } \\
\text { Probabilitas }\end{array}$} & \multicolumn{3}{|c|}{ Nilai Kritis Mc. Kinnon } & \multirow{2}{*}{ Keterangan } \\
\hline & & & 1 persen & 5 persen & 10 persen & \\
\hline LTD & -0.263562 & 0.9909 & -4.029595 & -3.444487 & -3.147063 & $\begin{array}{c}\text { Tidak } \\
\text { Stasioner }\end{array}$ \\
\hline IR & -2.578296 & 0.1001 & -3.480818 & -2.883579 & -2.578601 & $\begin{array}{c}\text { Tidak } \\
\text { Stasioner }\end{array}$ \\
\hline $\mathrm{CR}$ & -3.746885 & 0.0044 & -3.481623 & -2.883930 & -2.578788 & Stasioner \\
\hline CPI & -2.148853 & 0.5135 & -4.030729 & -3.445030 & -3.147382 & $\begin{array}{c}\text { Tidak } \\
\text { Stasioner }\end{array}$ \\
\hline IG & -12.47653 & 0.0000 & -3.481217 & -2.883753 & -2.578694 & Stasioner \\
\hline LR & -3.159534 & 0.0974 & -4.030729 & -3.445030 & -3.147382 & $\begin{array}{c}\text { Tidak } \\
\text { Stasioner }\end{array}$ \\
\hline
\end{tabular}


Tabel 3 Hasil pengujian akar unit tipe ADF pada first difference

\begin{tabular}{|c|c|c|c|c|c|c|}
\hline \multirow[b]{2}{*}{ Variabel } & \multirow{2}{*}{$\begin{array}{c}\text { ADF } \\
\text { Statistik }\end{array}$} & \multirow{2}{*}{$\begin{array}{c}\text { ADF } \\
\text { Probabilitas }\end{array}$} & \multicolumn{3}{|c|}{ Nilai Kritis Mc. Kinnon } & \multirow[b]{2}{*}{ Keterangan } \\
\hline & & & 1 persen & 5 persen & 10 persen & \\
\hline LTD & -10.75058 & 0.0000 & -4.030157 & -3.444756 & -3.147221 & Stasioner \\
\hline IR & -13.79342 & 0.0000 & -3.481217 & -2.883753 & -2.578694 & Stasioner \\
\hline CR & -3.151887 & 0.0018 & -2.583011 & -1.943324 & -1.615075 & Stasioner \\
\hline CPI & -9.398980 & 0.0000 & -4.030729 & -3.445030 & -3.147382 & Stasioner \\
\hline IG & -8.520402 & 0.0000 & -3.485586 & -2.885654 & -2.579708 & Stasioner \\
\hline LR & -5.335577 & 0.0001 & -4.030157 & -3.444756 & -3.147221 & Stasioner \\
\hline
\end{tabular}

Tabel 4 Hasil pengujian akar unit tipe PP pada level

\begin{tabular}{|c|c|c|c|c|c|c|}
\hline \multirow{2}{*}{ Variabel } & \multirow{2}{*}{ PP Statistik } & \multirow{2}{*}{$\begin{array}{c}\text { PP } \\
\text { Probabilitas }\end{array}$} & \multicolumn{3}{|c|}{ Nilai Kritis Mc. Kinnon } & \multirow{2}{*}{ Keterangan } \\
\hline & & & 1 persen & 5 persen & 10 persen & \\
\hline LTD & -0.306245 & 0.9897 & -4.029595 & -3.444487 & -3.147063 & $\begin{array}{c}\text { Tidak } \\
\text { Stasioner }\end{array}$ \\
\hline IR & -2.381759 & 0.1489 & -3.480818 & -2.883579 & -2.578601 & $\begin{array}{c}\text { Tidak } \\
\text { Stasioner }\end{array}$ \\
\hline CR & -2.651442 & 0.0855 & -3.480818 & -2.883579 & -2.578601 & $\begin{array}{c}\text { Tidak } \\
\text { Stasioner }\end{array}$ \\
\hline CPI & -2.424351 & 0.3645 & -4.029595 & -3.444487 & -3.147063 & $\begin{array}{c}\text { Tidak } \\
\text { Stasioner }\end{array}$ \\
\hline IG & -20.85539 & 0.0000 & -4.029595 & -3.444487 & -3.147063 & Stasioner \\
\hline LR & -1.680730 & 0.0877 & -2.582734 & -1.943285 & -1.615099 & $\begin{array}{c}\text { Tidak } \\
\text { Stasioner }\end{array}$ \\
\hline
\end{tabular}

Tabel 5 Hasil pengujian akar unit tipe PP pada first difference

\begin{tabular}{lcccccc}
\hline \multirow{2}{*}{ Variabel } & \multirow{2}{*}{ PP Statistik } & PP & \multicolumn{2}{c}{ Nilai Kritis Mc. Kinnon } & \\
\cline { 4 - 6 } & & & & & \\
\cline { 4 - 6 } & & & & & & \\
LTD & -10.81390 & 0.0000 & -4.030157 & -3.444756 & -3.147221 & Stasioner \\
IR & -14.05676 & 0.0000 & -3.481217 & -2.883753 & -2.578694 & Stasioner \\
CR & -5.702343 & 0.0000 & -3.481217 & -2.883753 & -2.578694 & Stasioner \\
CPI & -8.443765 & 0.0000 & -4.030157 & -3.444756 & -3.147221 & Stasioner \\
IG & -40.19112 & 0.0000 & -2.582872 & -1.943304 & -1.615087 & Stasioner \\
LR & -5.374775 & 0.0000 & -3.481217 & -2.883753 & -2.578694 & Stasioner \\
\hline
\end{tabular}

Setelah mengetahui seluruh variabel stasioner pada tingkat first difference, selanjutnya dilakukan pengujian lag optimal yang digunakan dalam model. Berdasarkan nilai AIC, lag optimal untuk model penelitian ini berada pada lag 3. Kemudian, dilakukan uji stabilitas VAR dan didapatkan hasil bahwa keseluruhan model stabil. Uji terakhir dalam uji pra estimasi adalah uji kointegrasi, uji ini dilakukan untuk melihat apakah terdapat hubungan jangka panjang antar variabel dalam model. Pada hasil uji 
kointegrasi model penelitian ini, terlihat bahwa variabel-variabel dalam model penelitian ini saling terkointegrasi.

Tabel 6 Hasil uji kointegrasi

\begin{tabular}{ccccc}
\hline $\begin{array}{c}\text { Hypothesized } \\
\text { No. of CE(s) }\end{array}$ & Eigenvalue & Statistic & $\begin{array}{c}0.05 \\
\text { Critical Value }\end{array}$ & Prob.** \\
\hline None $*$ & 0.455702 & 167.2993 & 107.3466 & 0.0000 \\
At most $1 *$ & 0.257654 & 89.44227 & 79.34145 & 0.0071 \\
At most 2 & 0.198513 & 51.30595 & 55.24578 & 0.1064 \\
At most 3 & 0.117664 & 22.98124 & 35.01090 & 0.5099 \\
At most 4 & 0.050705 & 6.957870 & 18.39771 & 0.7860 \\
At most 5 & 0.002320 & 0.297316 & 3.841466 & 0.5856 \\
\hline
\end{tabular}

Trace test indicates 2 cointegrating eqn(s) at the 0.05 level

*denotes rejection of the hypothesis at the 0.05 level

**MacKinnon-Haug-Michelis (1999) p-values

Berdasarkan hasil uji pra estimasi di atas terdapat beberapa data yang tidak stasioner pada tingkat level dan adanya kointegrasi dari tiap variabel dalam model. Maka dapat disimpulkan bahwa untuk menjelaskan pengaruh krisis keuangan global dan variabel makroekonomi terhadap total deposito pada perbankan syariah di Indonesia digunakan model VECM.

\section{Hasil Penelitian}

Hasil estimasi VECM menunjukkan nilai t-statistic dummy crisis sebesar [-0.24115] dan koefisien dummy crisis sebesar -0.002268. Hal ini menunjukkan bahwa krisis keuangan global tidak memiliki pengaruh terhadap total deposito pada perbankan syariah di Indonesia. Hasil ini sesuai dengan penelitian yang dilakukan oleh Karim et al. (2012) yang mengatakan bahwa simpanan dalam perbankan syariah lebih stabil menghadapi krisis, hal ini dapat terjadi karena penerapan profit sharing pada sistem perbankan syariah sehingga krisis keuangan yang menyebabkan Bank Indonesia menaikkan BI rate untuk meredam inflasi yang diakibatkan oleh turunnya nilai rupiah terhadap dolar tidak berpengaruh secara langsung.

\section{Uji Kausalitas}

Untuk melihat pengaruh antara satu variabel dengan variabel yang lain dalam penelitian ini digunakan metode Granger-Causality. Hal tersebut untuk menguji kesesuaian dengan teori dan tujuan penelitian ini. Hasil uji kausalitas dapat dilihat pada Tabel 7.

Dari hasil Granger-Causality di atas dapat dilihat bahwa hampir seluruh variabel tidak saling mempengaruhi kecuali tingkat bagi hasil perbankan syariah dan suku bunga perbankan konvensional terhadap suku bunga pinjaman. Dapat dilihat bahwa variabel tingkat bagi hasil (IR) secara statistik signifikan mempengaruhi suku bunga pinjaman (LR) dan begitu pula suku bunga perbankan konvensional (CR) secara statistik juga signifikan memengaruhi variabel suku bunga pinjaman (LR) yang dibuktikan dengan nilai Prob secara berurutan lebih kecil dari 0.05 , yaitu secara 0.0002 dan 0.0039. Selain itu juga tingkat bagi hasil perbankan syariah juga terbukti secara statistik signifikan mempengaruhi total deposito perbankan syariah dengan nilai Prob 0.0228. Hal ini sangat jelas sesuai dengan teori yang ada, yakni semakin tinggi tingkat bagi hasil, maka masyarakat akan semakin tertarik untuk menyimpan dana mereka di bank. Aziz et al. (2014) dalam penelitiannya pun menunjukkan bahwa dalam jangka pendek tingkat bagi hasil berpengaruh signifikan terhadap jumlah deposito pada bank syariah. 
Tabel 7 Hasil Granger-Causality

\begin{tabular}{lcr}
\hline Null Hypothesis & F-Statistic & \multicolumn{1}{c}{ Prob. } \\
\hline LR does not Granger Cause LTD & 1.00280 & 0.3698 \\
LTD does not Granger Cause LR & 1.21308 & 0.3008 \\
\hline IR does not Granger Cause LTD & 0.29535 & 0.7448 \\
LTD does not Granger Cause IR & 3.89704 & $0.0228^{*}$ \\
\hline IG does not Granger Cause LTD & 0.06016 & 0.9416 \\
LTD does not Granger Cause IG & 0.98092 & 0.3778 \\
\hline CR does not Granger Cause LTD & 1.39108 & 0.2526 \\
LTD does not Granger Cause CR & 0.84158 & 0.4335 \\
\hline CPI does not Granger Cause LTD & 0.28210 & 0.7547 \\
LTD does not Granger Cause CPI & 1.38348 & 0.2545 \\
\hline IR does not Granger Cause LR & 1.42740 & 0.2438 \\
LR does not Granger Cause IR & 9.32841 & $0.0002^{*}$ \\
\hline IG does not Granger Cause LR & 0.13395 & 0.8748 \\
LR does not Granger Cause IG & 0.69177 & 0.5026 \\
\hline CR does not Granger Cause LR & 11.2845 & $3 . \mathrm{E}-05^{*}$ \\
LR does not Granger Cause CR & 5.81027 & $0.0039^{*}$ \\
\hline CPI does not Granger Cause LR & 1.13505 & 0.3247 \\
LR does not Granger Cause CPI & 1.56388 & 0.2134 \\
\hline IG does not Granger Cause IR & 0.77118 & 0.4647 \\
IR does not Granger Cause IG & 2.34933 & $0.0996^{*}$ \\
\hline CR does not Granger Cause IR & 11.7219 & $2 . \mathrm{E}-05^{*}$ \\
IR does not Granger Cause CR & 2.62771 & 0.0762 \\
\hline CPI does not Granger Cause IR & 0.79615 & 0.4533 \\
IR does not Granger Cause CPI & 0.24068 & 0.7865 \\
\hline CR does not Granger Cause IG & 0.19625 & 0.8221 \\
IG does not Granger Cause CR & 0.20567 & 0.8144 \\
\hline CPI does not Granger Cause IG & 1.32360 & 0.2699 \\
IG does not Granger Cause CPI & 0.98182 & 0.3775 \\
\hline CPI does not Granger Cause CR & 0.38418 & 0.4818 \\
CR does not Granger Cause CPI & 0.90603 \\
\hline Ken & &
\end{tabular}

Ket: Lags: 2

Obs: 130

\section{Analisis Impulse Response Function (IRF)}

Respon suatu variabel akibat saat terjadi guncangan pada variabel lainnya dapat dilihat dengan analisis IRF, tersedia pada Gambar 1. Pada penelitian ini akan dilihat respon variabel dari total deposito pada perbankan syariah di Indonesia terhadap variabel makroekonomi.

Respon total deposito terhadap tingkat bagi hasil perbankan syariah dapat dilihat pada grafik IRF di atas. Total deposito belum merespon guncangan tingkat bagi hasil perbankan syariah pada periode pertama. Pada periode kedua total deposito merespon positif sebesar 0.004 persen dan mengalami kenaikan respon hingga periode keempat sebesar 0.009 persen namun turun pada periode kelima menjadi 0.006 persen dan periode kesepuluh sebesar 0.005 persen dan mengalami kenaikan terus menerus hingga stabil pada periode ke-26 dengan respon positif dalam kisaran angka 0.006 persen. Guncangan tingkat bagi hasil selalu direspon positif oleh total deposito, hal ini disebabkan semakin tinggi tingkat bagi hasil yang ditawarkan oleh perbankan syariah, nasabah akan semakin tertarik untuk menyimpan dana pada produk deposito. 
Response to Cholesky One S.D. Innovations

Response of LTD to LTD

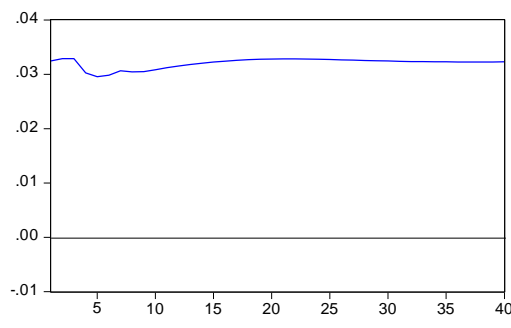

Response of LTD to CR

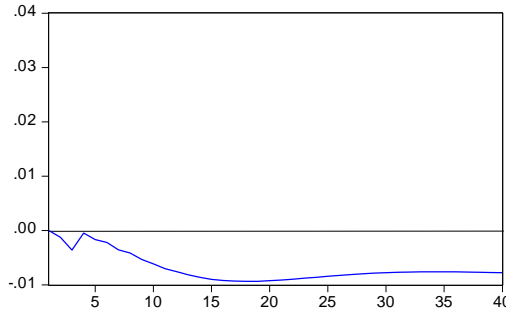

Response of LTD to IG

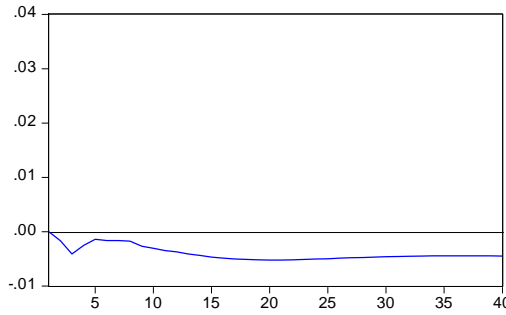

Response of LTD to IR

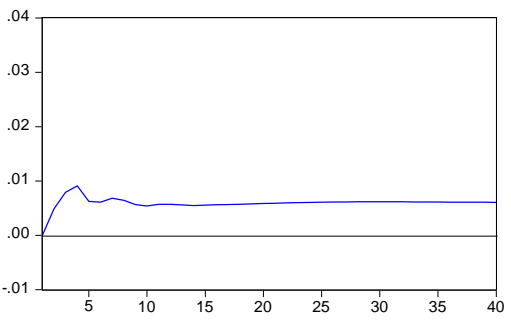

Response of LTD to CPI

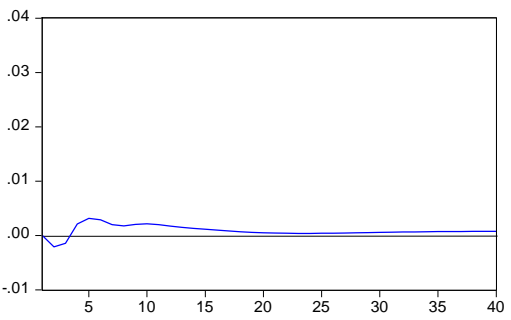

Response of LTD to LR

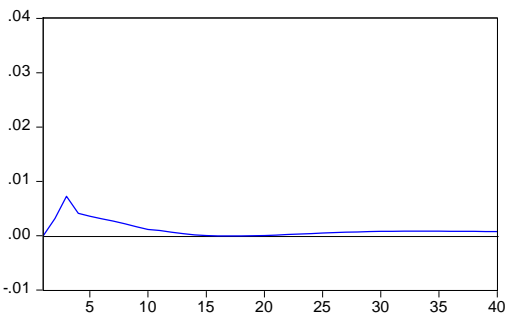

Gambar 1 Grafik IRF total deposito

Guncangan suku bunga deposito bank konvensional sebesar satu standar deviasi akan direspon negatif oleh total deposito yang mulai tampak pada periode kedua sebesar -0.001 persen, respon yang diberikan oleh total deposito selalu negatif hingga mencapai kestabilan pada kisaran -0.007. Maka guncangan suku bunga deposito bank konvensional selalu direspon negatif oleh total deposito, hal ini disebabkan oleh semakin tingginya suku bunga deposito yang dijanjikan pada perbankan konvensional akan membuat para nasabah beralih kepada perbankan konvensional dan menurunkan total deposito pada perbankan syariah.

Pada grafik IRF, guncangan inflasi yang diwakilkan oleh consumer price index sebesar satu standar deviasi direspon negatif oleh total deposito yang mulai tampak pada periode kedua yakni sebesar 0.002 persen dan periode ketiga sebesar -0.001 persen. Namun pada periode ke empat respon total deposito terhadap inflasi menjadi positif dengan nilai 0.002 persen meskipun terus mengalami penurunan hingga mencapai kestabilan pada kisaran 0.0007 persen. Hal ini menunjukkan saat terjadi inflasi, maka akan menyebabkan total deposito mengalami kenaikan yang disebabkan ketika hargaharga naik, banyak perusahaan yang mengalami kenaikan pendapatan dan menyimpan uang di bank, dan simpanan yang menguntungkan adalah deposito. Selain itu, grafik IRF menunjukkan respon negatif total deposito terhadap guncangan pertumbuhan industri sebesar satu standar deviasi dengan nilai -0.001 persen pada periode kedua, dan turun pada periode ke empat sebesar -0.004 persen. Respon total deposito terhadap pertumbuhan industri selalu direspon negatif hingga mencapai kestabilan pada periode ke tiga belas dengan kisaran nilai -0.004 persen. Ini disebabkan semakin baik pertumbuhan industri, masyarakat lebih tertarik untuk menginvestasikan dana yang ada kepada sektor riil dibandingkan harus menyimpan pada simpanan berjangka atau deposito. 
Hasil IRF juga menunjukkan bahwa guncangan suku bunga pinjaman sebesar satu deviasi pada periode pertama belum direspon oleh total deposito. Lalu pada periode kedua guncangan suku bunga pinjaman direspon positif sebesar 0.003 persen dan 0.007 persen pada periode ketiga. Namun pada periode ke empat hingga ke tujuh respon mengalami penurunan berturut-turut sebesar 0.004 dan 0.002 persen. Kemudian pada periode ke delapan dan seterusnya mengalami fluktuasi hingga mencapai kestabilan dengan nilai positif pada kisaran 0.0007 persen. Hal ini disebabkan semakin tinggi suku bunga pinjaman, masyarakat cenderung tidak akan meminjam dana pada lembaga keuangan namun lebih memilih menyimpan dana pada perbankan dalam produk simpanan berjangka atau deposito karena lebih menguntungkan.

\section{Analisis Forecast Error Variance Decomposition (FEVD)}

Berdasarkan hasil analisis dekomposisi varian, secara umum dapat disimpulkan bahwa pada periode pertama, fluktuasi total deposito disebabkan oleh guncangan total deposito itu sendiri, yakni sebesar 100 persen. Kontribusi faktor guncangan variabel variabel lain terhadap total deposito baru mulai terlihat pada periode ke dua hingga periode keempat0. Pada periode kedua kontribusi guncangan tingkat bagi hasil perbankan syariah memiliki peranan sebesar 1.07 persen terhadap fluktuasi total deposito, kemudian suku bunga deposito perbankan konvensional memberikan kontribusi varian sebesar 0.07 persen, diikuti dengan consumer price index sebesar 0.2 persen, pertumbuhan industri sebesar 0.13 persen dan suku bunga pinjaman sebesar 0.45 persen terhadap fluktuasi total deposito. Dalam periode selanjutnya, masing-masing variabel memiliki nilai variatif yang mengalami kenaikan dan penurunan dalam memberikan pengaruh terhadap total deposito.

Namun, pada hasil analisis FEVD menunjukkan bahwa tingkat bagi hasil perbankan syariah dan suku bunga deposito perbankan konvensional adalah variabel yang paling dominan dalam memberikan pengaruh terhadap total deposito perbankan syariah dibandingkan dengan variabel lainnya berturut turut pada kisaran angka sebesar 3.1 persen dan 4.6 persen. Variabel lainnya memberikan kontribusi dengan nilai tidak lebih dari pada 2.0 persen hingga dekomposisi dari total deposito perbankan syariah mencapai kestabilan. Total deposito perbankan syariah yang dipengaruhi oleh komposisi dari kelima faktor tersebut stabil pada kisaran angka 89.7 persen. Komposisi dan kontribusi faktor-faktor tersebut pada tiap-tiap periode dapat terlihat pada Gambar 2.

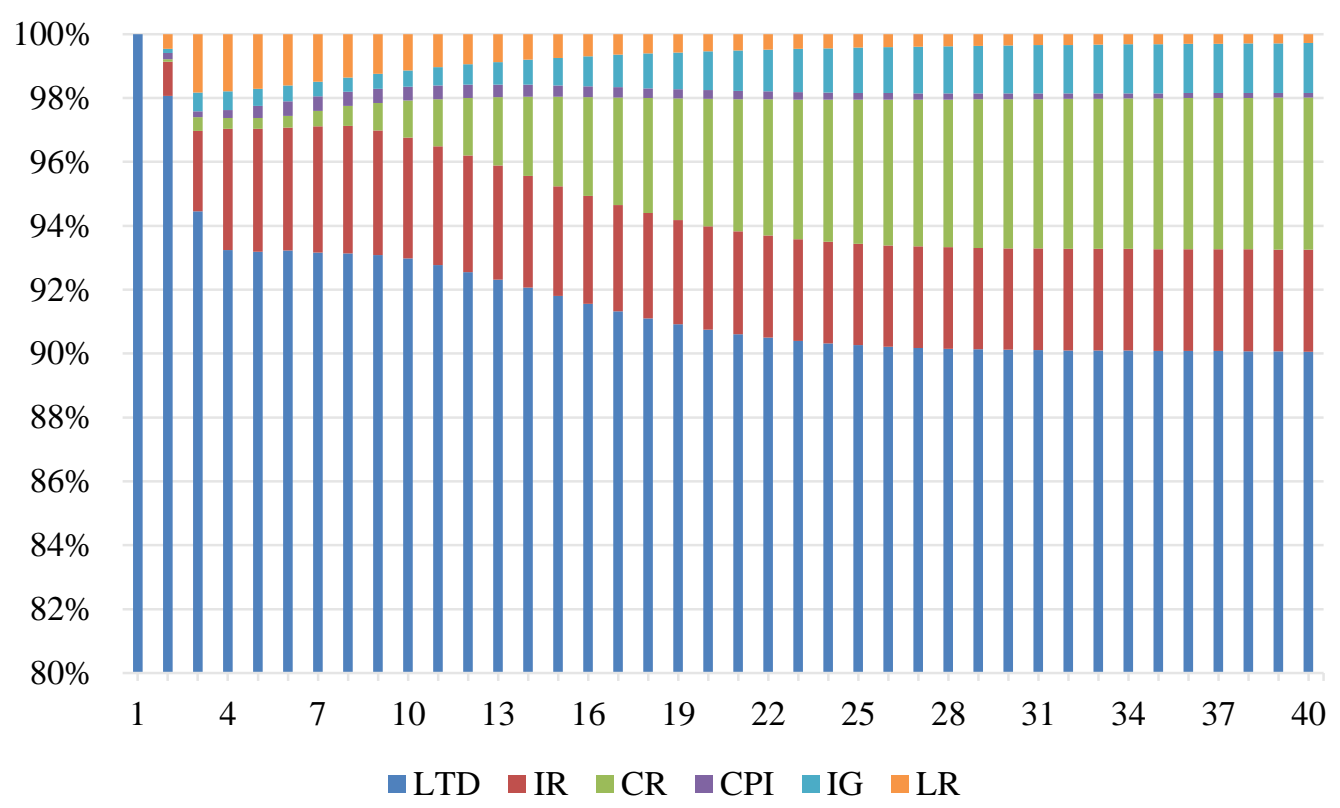

Gambar 2 FEVD Total Deposito 


\section{SIMPULAN DAN SARAN}

\section{Simpulan}

Berdasarkan hasil estimasi VECM, krisis keuangan global tidak berpengaruh terhadap total deposito pada perbankan syariah di Indonesia. Hal ini menunjukkan bahwa perbankan syariah memiliki kondisi yang lebih stabil saat menghadapi krisis keuangan global di tahun 2008 dibandingkan dengan perbankan konvensional. Kemudian dari hasil analisis IRF dan FEVD, membuktikan hipotesis bahwa keberadaan perbankan syariah saat ini sangat dipengaruhi oleh perbankan konvensional, khususnya dalam pengelolaan Dana Pihak Ketiga. Hal ini menjadi wajar dikarenakan bank konvensional seperti BNI, Bank Mandiri, BCA, Bank BTN, dan lainnya didirikan lebih dahulu dibandingkan bank-bank syariah. Sehingga menyerap nasabah lebih banyak. Di samping itu, orang-orang terkaya di Indonesia adalah non-muslim, sehingga wajar bila bank konvensional sangat dominan berdasarkan analisis FEVD.

\section{Saran}

Berdasarkan dari hasil penelitian ini, maka terdapat beberapa saran yang dapat diberikan, yaitu:

1 Perbankan syariah sebaiknya melakukan inovasi pada produk deposito mudharabah. Salah satunya adalah dengan merumuskan tingkat bagi hasil deposito atau equivalent rate yang dapat bersaing dengan suku bunga deposito perbankan konvensional guna meningkatkan total jumlah dana deposito masyarakat yang merupakan produk paling dominan dari Dana Pihak Ketiga (DPK) pada perbankan syariah sehingga pembiayaan yang dilakukan oleh perbankan syariah lebih lancar dan mendapatkan peluang untuk mendapatkan laba lebih banyak.

2 Untuk dapat bersaing dengan market share dominasi perbankan konvensional, perbankan syariah memerlukan analis pembiayaan syariah yang handal untuk menarik nasabah pembiayaan lebih banyak dengan meningkatkan tingkat bagi hasil yang dijanjikan tanpa adanya pembiayaan yang macet.

3 Penelitian selanjutnya dapat menambah periode pengamatan dan memperluas cakupan penelitian dengan menggunakan negara lain sebagai objek pengamatan. Selain itu, dapat juga menambah variabel karakteristik bank lainnya yang berhubungan dengan produk deposito secara tidak langsung seperti Financing Deposit Ratio (FDR) dan Non Performing Finance (NPF) atau menggunakan metode statistika lain dalam pengolahan data untuk mendapatkan hasil yang lebih akurat.

\section{DAFTAR PUSTAKA}

Abduh, M., Omar, M.A., \& Duasa, J. (2011) The impact of crisis and macroeconomic variables towards islamic banking deposits. American Journal of Applied Sciences, 8(12), 1413-1418.

Aziz, H.A., Musse, O.S.H., \& Echchabi, A. (2014) Factors determining Islamic banks' deposits in Qatar: An empirical study. International Journal of Economic Practices and Theories, 4(6), 987-994.

Beck, T., Demirguc-Kunt, A., \& Merrouche, O. (2010) Islamic vs. conventional banking: Business model, efficiency, and stability. World Bank Policy Reseacrh Working Paper.

[BI] Bank Indonesia. (2011) Statistik Perbankan Indonesia Desember 2011 [internet]. [diunduh 2016Feb23]. Tersedia pada: http://www.bi.go.id

. (2010) Statistik Perbankan Indonesia Desember 2010 [internet]. [diunduh 2016 Feb 23]. Tersedia pada: http://www.bi.go.id

(2009) Statistik Perbankan Indonesia Desember 2009 [internet]. [diunduh 2016 Feb 23]. Tersedia pada: http://www.bi.go.id

(2008) Statistik Perbankan Indonesia Desember 2008 [internet]. [diunduh

2016 Feb 23]. Tersedia pada: http://www.bi.go.id

(2007) Statistik Perbankan Indonesia Desember 2007 [internet]. [diunduh

2016 Feb 23]. Tersedia pada: http://www.bi.go.id 
(2006) Statistik Perbankan Indonesia Desember 2006 [internet]. [diunduh 2016 Feb 23]. Tersedia pada: http://www.bi.go.id . (2005) Statistik Perbankan Indonesia Desember 2005 [internet]. [diunduh 2016 Feb 23]. Tersedia pada: http://www.bi.go.id

Chong, B.S. \& Liu, M.H. (2008) Islamic banking: Interest-free or interest based?. Pasific-Basin Finance Journal, 17(1), 125-144.

Haron, S. \& Azmi, W.N.W. (2008) Determinants of Islamic and conventional deposits in the Malaysian banking system. Managerial Finance, 34, 618-643.

Karim, A.( 2003) Bank Islam: Analisis Fiqih dan Keuangan. Jakarta, IIIT Indonesia.

Karim, B.A., Lee, W.S., Karim, Z.A., \& Jais, M. (2012) The impact of subprime mortgage crisis on Islamic banking and Islamic stock market. International Congress on Interdisciplinary Business and Social Science 2012.

Kasim, S.H., Majid, M.S.A., \& Yusof, R.M. (2009) Impact of monetary policy shocks on the conventional and Islamic banks in a dual banking system: Evidence from Malaysia. Journal. Econ. Coop. Dev, 30(1), 41-58.

Sugema, I. (2012) Krisis keuangan global 2008-2009 dan implikasinya pada perekonomian Indonesia. Jurnal Ilmu Pertanian Indonesia (JIPI), 17(3), 145-152.

[OJK] Otoritas Jasa Keuangan. (2016) Statistik Perbankan Syariah Indonesia Desember 2016 [internet]. [diunduh 2016 Feb 23]. Tersedia pada: http://www.ojk.go.id

. (2015) Statistik Perbankan Syariah Indonesia Desember 2015 [internet]. [diunduh 2016 Feb 23]. Tersedia pada: http://www.ojk.go.id

. (2014) Statistik Perbankan Syariah Indonesia Desember 2014

[internet]. [diunduh 2016 Feb 23]. Tersedia pada: http://www.ojk.go.id

(2013) Statistik Perbankan Syariah Indonesia Desember 2013

[internet]. [diunduh 2016 Feb 23]. Tersedia pada: http://www.ojk.go.id

(2012) Statistik Perbankan Syariah Indonesia Desember 2012

[internet]. [diunduh 2016 Feb 23]. Tersedia pada: http://www.ojk.go.id. 